\title{
Heats of Copolymerization of Butadiene and Styrene from Measurements of Heats of Combustion
}

\author{
Raymond A. Nelson, Ralph S. Jessup, and Donald E. Roberts
}

\begin{abstract}
The heats of combustion of two samples of polybutadiene and four copolymers of butadiene and styrene prepared at $50^{\circ} \mathrm{C}\left(122^{\circ} \mathrm{F}\right)$, and one sample of polybutadiene and four copolymers polymerized at $5^{\circ} \mathrm{C}\left(41^{\circ} \mathrm{F}\right)$ were measured in a bomb calorimeter. The styrene contents in the copolymers varied from approximately 8 to 55 weight percent.

A value for the heat of polymerization (or copolvmerization) was calculated for each sample by combining the experimental value for the heat of combustion with other known thermochemical data. The mean value obtained for the heat of polymerization $\left(-\Delta H_{p}^{\circ}\right)$ of polybutadiene is $17.4 \mathrm{kcal}$ per monomer unit, and the values obtained for the heat of copolymerization varied from 17.1 to $17.7 \mathrm{kcal}$ per monomer unit. No apperciable difference was found between the heats of copolymerization of the $5^{\circ} \mathrm{C}$ and $50^{\circ} \mathrm{C}$ polymers. The heat of copolymerization can be represented as a function of styrene content of the polymer by an equation of a form derived theoretically by Alfrey and Lewis, although the conditions under which the polymers were formed were such that some of the assumptions underlying the derivation of the equation were not satisfied.
\end{abstract}

\section{Introduction}

Measurements have been made, by means of a bomb calorimeter, of the heats of combustion of three samples of polybutadiene and eight copolymers of butadiene and styrene, ranging in styrene content from approximately 8 to 55 percent by weight ( 5 to 40 mole \%). Two of the samples of polybutadiene and four of the copolymers were prepared by polymerization at $50^{\circ} \mathrm{C}\left(122^{\circ} \mathrm{F}\right)$, whereas the others were polymerized at $5^{\circ} \mathrm{C}\left(41^{\circ} \mathrm{F}\right)$. The data have been combined with other thermochemical data to obtain values for heats of polymerization and copolymerization.

\section{Source and Purity of Material}

The materials used in this investigation were made available by the Reconstruction Finance Corp., Office of Rubber Reserve, and were purified in the Rubber Section of the Bureau. Some of the properties of the purified materials are given in table 1. The polymers were prepared by emulsion polymerization. The "modifiers" used were commercial $n$-dodecyl mercaptan (DDM) for the $50^{\circ} \mathrm{C}$ polymers, and commercial tert-dodecyl mercaptan (Sulfole) for the $5^{\circ} \mathrm{C}$ polymers.

The purification procedure involved dissolving the sample in benzene and precipitating it by pouring the solution slowly into methyl alcohol while stirring. This was done three times. Then the purified sample was again dissolved in benzene, a small amount of phenyl-beta-naphtbylamine was added as an antioxidant, the mixture was frozen, and the benzene was removed by sublimation in vacuum to give a product similar to foam rubber in appearance. This procedure removed soap, fatty acid, and stabilizer, as well as some of the low-molecular-weight polymer. In the present work no significant difference was found in the heats of combustion of samples burned as received after the treatment
TABLE 1. Analyses of polymer samples

\begin{tabular}{|c|c|c|c|c|c|c|c|}
\hline Polymer & $\begin{array}{l}\text { Sty- } \\
\text { rene }\end{array}$ & $\begin{array}{l}\text { Car- } \\
\text { bon }\end{array}$ & $\begin{array}{c}\text { Hydro- } \\
\text { gen }\end{array}$ & $\begin{array}{l}\text { Oxy- } \\
\text { gen }\end{array}$ & $\begin{array}{l}\text { Sul- } \\
\text { fur }\end{array}$ & Ash & $\begin{array}{l}\text { Phenyl- } \\
\text { beta- } \\
\text { naphthyl- } \\
\text { amine }\end{array}$ \\
\hline \multicolumn{8}{|c|}{$50^{\circ} \mathrm{C}\left(122^{\circ} \mathrm{F}\right)$ polymers } \\
\hline $\begin{array}{l}\text { A } \\
\text { GL-657 } \\
\text { GL-658 } \\
\text { X-452 } \\
\text { GL-662 } \\
48-B\end{array}$ & $\begin{array}{l}\text { wet \% } \\
0 \\
0 \\
8.58 \\
2389 \\
42.98 \\
55.73\end{array}$ & $\begin{array}{l}w t \% \\
88.486 \\
88.656 \\
88.907 \\
89.42 \\
90.100 \\
90.561\end{array}$ & $\begin{array}{c}\text { wt } \% \\
11.166 \\
11.1795 \\
10.8982 \\
10.36 \\
9.7100 \\
9.2643\end{array}$ & $\begin{array}{l}w t \% \\
0.145 \\
.145 \\
.16 \\
.096 \\
.14 \\
.15\end{array}$ & $\begin{array}{l}w t \% \\
0.109 \\
b .072 \\
.136 \\
.087 \\
.081 \\
.046\end{array}$ & $\begin{array}{l}w t \% \\
0.100 \\
.097 \\
.104 \\
.13 \\
.111 \\
.158\end{array}$ & $\begin{array}{c}w t \%^{a} \\
0.00 \\
.12 \\
.1 \\
.07 \\
1 \\
.07\end{array}$ \\
\hline \multicolumn{8}{|c|}{$5^{\circ} \mathrm{C}\left(41^{\circ} \mathrm{F}\right)$ polymers } \\
\hline $\begin{array}{l}\text { B } \\
X-454 \\
X-478 \\
\text { GL-660 } \\
\text { GL }-661\end{array}$ & $\begin{array}{c}0 \\
8.58 \\
22.61 \\
36.26 \\
53.09\end{array}$ & $\begin{array}{l}88.474 \\
88.869 \\
89.443 \\
89.913 \\
90.513\end{array}$ & $\begin{array}{r}11.1600 \\
10.872 \\
10.4008 \\
9.9342 \\
9.3585\end{array}$ & $\begin{array}{l}0.12 \\
.235 \\
.15 \\
.08 \\
.11\end{array}$ & $\begin{array}{l}0.083 \\
\text { ๖. } 056 \\
.048 \\
.050 \\
.045\end{array}$ & $\begin{array}{l}0.34 \\
.18 \\
.098 \\
.095 \\
.097\end{array}$ & $\begin{array}{l}0.14 \\
.13 \\
.11 \\
.11 \\
.11\end{array}$ \\
\hline
\end{tabular}

a Added after analysis.

$b$ The values reported here are corrected values for sulfur content. For GL-657 the experimentally determined value is $0.150 \% \mathrm{~S}$ and for $\mathrm{X}-4540.087 \% \mathrm{~S}$. See text p. 275 .

described above and after further evacuation to about $10^{-4} \mathrm{~mm}$ of mercury for several days at room temperature.

The purified samples were analyzed quantitatively, and the results are reported in table 1 . The styrene contents reported in this table were calculated from the carbon-hydrogen ratios (corrected for mercaptan).

A part of the experimentally determined sulfur content of sample $\mathrm{X}-454$ was found to be present as an inorganic impurity, rather than as mercaptan attached to the polymer chain. The sulfur content reported in table 1 for this sample is the excess of the total observed sulfur over that found to be present in the inorganic impurity. The experimentally determined sulfur content of sample GL-657, which contained no styrene, was higher than that calculated from the observed carbon-hydrogen ratio on the as- 
sumption that the sample consisted entirely of dodecyl mercaptan and polybutadiene. It was assumed that the difference was due to sulfur in inorganic impurity (as in the case of sample $\mathrm{X}-454$ ), and the sulfur content reported is that calculated from the carbon-hydrogen ratio.

\section{Method and Apparatus}

The apparatus and procedure used in the bomb calorimetric measurements have been described previously $[1,2,3,12] .{ }^{1}$ The bomb used has a capacity of $381 \mathrm{ml}$. One milliliter of water was piaced in the bomb before each combustion experiment. The polymer samples used were first compressed into pellets.

The calorimetric system was calibrated with NBS Standard Sample $39 \mathrm{~g}$ of benzoic acid, using the value $26433.8 \mathrm{abs} \mathrm{j} / \mathrm{g}$ for the heat of combustion of this material under the conditions of the standard bomb process $[3,4,5]$.

In calculating the results of the heat of combustion measurements, the amount of the combustion reaction in each experiment was determined from the mass of carbon dioxide formed, using the value 44.010 $\mathrm{g}$ for the molecular weight of carbon dioxide [21]. Tests were made for carbon monoxide in the gaseous products of combustion after the carbon dioxide had been removed, using a colorimetric method developed at the Bureau [6]. No carbon monoxide was found, and no soot or other evidence of incomplete combustion was found in the bomb in any experiment.

Corrections were applied to the observed heat of combustion in each experiment for heat of stirring, heat transfer between calorimeter and surroundings, ignition energy $(22 \mathrm{j})$, and energy produced by the formation of aqueous nitric $(58.8 \mathrm{kj} / \mathrm{mole})$ and sulfuric $(305.7 \mathrm{kj} / \mathrm{mole})$ acids in the bomb. The last two corrections were made on the basis of the analysis of the washings from the bomb after each combustion experiment. The air initially in the bomb was not flushed out with oxygen in these experiments. The atmospheric nitrogen was left in the bomb because the oxides of nitrogen are known to catalyze the formation of sulfuric acid from sulfur dioxide, oxygen, and water.

The aqueous solution in the bomb at the end of each experiment was analyzed for the acids formed during the combustion by first determining the total acidity of the bomb washings by titration with a standard solution of sodium hydroxide, using methyl orange as the indicator, then removing the nitrate by evaporating the solution to dryness, and finally, determining the sulfur by precipitation as barium sulfate and weighing. The percentage of sulfur so determined averaged 0.01 lower than the values reported in table 1 . The total correction for acids did not amount to more than 0.2 percent of the total heat produced in the combustion reaction.

The observed heat of combustion, $-\Delta U_{B}$, in each experiment was reduced to the value of $-\Delta U_{c}^{\circ}$, the

${ }_{1}^{1}$ Figures in brackets indicate the literature references at the end of this paper decrease in intrinsic energy accompanying the reaction

$$
\begin{gathered}
\mathrm{C}_{a} \mathrm{H}_{b} \mathrm{O}_{c} \mathrm{~S}_{d} \text { (solid polymer) }+\left(a+d+\frac{b-2 c}{4}\right) \mathrm{O}_{2}(\mathrm{~g}) \longrightarrow \\
a \mathrm{CO}_{2}(\mathrm{~g})+d \mathrm{SO}_{2}(\mathrm{~g})+\frac{b}{2} \mathrm{H}_{2} \mathrm{O} \text { (liq) },
\end{gathered}
$$

using the Washburn procedure [7] modified so as to apply to $28^{\circ} \mathrm{C}$ and to the energy content of the gases at zero pressure instead of $1 \mathrm{~atm}$.

The measurements were made in terms of the absolute joule as the unit of energy. Conversion to the conventional thermochemical calorie was made by means of the relation

$$
1 \mathrm{cal}=4.1840 \text { abs j. }
$$

\section{Results of the Calibration Experiments}

All the measurements of heat of combustion reported in this paper were made with the same calorimetric system. However, the work was carried out over a period of about 2 years, and, because of necessary repairs to the calorimetric system, it was recalibrated several times during the course of the work. Table 2 presents a summary of the values obtained for the energy equivalent of the calorimeter and the numbers of the polymer samples whose heats of combustion were measured, using each value for

\begin{tabular}{|c|c|}
\hline Energy equivalent & Polymers investigated \\
\hline $\begin{array}{l}j /{ }^{\circ} \mathrm{C} \\
13784.4 \pm 0.7^{a} \\
13972.2 \pm 0.8 \\
13970.2 \pm 1.8 \\
13964.9 \pm 1.8 \\
13956.7 \pm 1.4 \\
13956.9 \pm 1.4 \\
13943.4 \pm 0.5 \\
13933.1 \pm 1.0\end{array}$ & 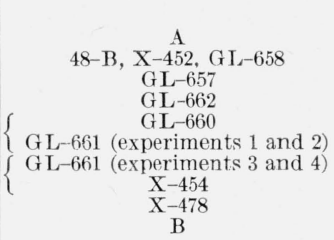 \\
\hline
\end{tabular}
the energy equivalent.

TABLE 2. Energy equivalent of calorimeter

$a$ The numbers following the \pm signs are the standard deviations of the corresponding mean values of energy equivalent.

\section{Experimental Results}

The results of the heat of combustion experiments are reported in tables 3 and 4 , where $-\Delta U_{B}$ represents the observed heat of combustion at $28^{\circ} \mathrm{C}$ under the conditions specified by the volume $(381 \mathrm{ml})$ of the bomb, the mass $(1 \mathrm{~g})$ of water placed in the bomb before each experiment, the temperature $\left(28^{\circ} \mathrm{C}\right)$ to which the combustion reaction is referred, and the data given in columns 3 and 5 ; and where $-\Delta U_{c}^{\circ}$ represents the decrease in intrinsic energy accompanying reaction (1) with all the reactants and products in their standard thermodynamic states at $28^{\circ} \mathrm{C}$. (The data on sample $\mathrm{A}$ of $50^{\circ} \mathrm{C}$ polybutadiene are for $30^{\circ}$ C.) 
TABLE 3. Results of bomb-calorimetric measurements $50^{\circ} \mathrm{C}$ polymers

\begin{tabular}{|c|c|c|c|c|c|}
\hline \multirow{2}{*}{ Experiment } & \multirow{2}{*}{$\begin{array}{l}\text { Mass of } \\
\text { sample }\end{array}$} & \multirow{2}{*}{$\underset{\mathrm{CO}_{2}}{\text { Mass of }}$} & \multirow{2}{*}{$\begin{array}{c}\text { Initial } \mathrm{O}_{2} \\
\text { pressure } \\
\text { at } 28^{\circ} \mathrm{C}\end{array}$} & \multicolumn{2}{|c|}{$\begin{array}{l}\text { Energy of combustion } \\
\text { at } 28^{\circ} \mathrm{C} \text {. }\end{array}$} \\
\hline & & & & $-\Delta U_{B}$ & $-\Delta U_{c}^{\circ}$ \\
\hline \multicolumn{6}{|c|}{ Sample $A^{a}$} \\
\hline $\begin{array}{l}1 \\
2 \\
3 \\
4\end{array}$ & $\begin{aligned} & g \\
& 0.90914 \\
& .92983 \\
& .90266 \\
& .90516\end{aligned}$ & $\begin{array}{l}g \\
\text { 2. } 94555 \\
\text { 3. } 01269 \\
\text { 2. } 92347 \\
\text { 2. } 93225\end{array}$ & $\begin{array}{l}\text { atm } \\
31.9 \\
31.9 \\
32.0 \\
32.2\end{array}$ & $\begin{array}{l}j / g \mathrm{CO}_{2} \\
13878 \cdot 2 \\
13884.5 \\
13883.4 \\
13882.0\end{array}$ & $\begin{array}{l}j / g \mathrm{CO}_{2} \\
13872.8 \\
13879.2 \\
13878.0 \\
13876.6\end{array}$ \\
\hline \multicolumn{5}{|c|}{$\begin{array}{l}\text { Mean } \\
\text { Standard deviation of the mean }\end{array}$} & $\begin{array}{r}13876.6 \\
\quad \pm 1.7\end{array}$ \\
\hline \multicolumn{6}{|c|}{ Sample GL-657 } \\
\hline $\begin{array}{l}1 \\
2 \\
3 \\
4 \\
5 \\
6\end{array}$ & $\begin{array}{r}0.93720 \\
.86631 \\
.89738 \\
.83177 \\
.89462\end{array}$ & $\begin{array}{l}\text { 3. } 04067 \\
\text { 2. } 81143 \\
\text { 2. } 91277 \\
\text { 2. } 70001 \\
\text { 2. } 85568 \\
\text {. } 90321\end{array}$ & $\begin{array}{l}31.8 \\
32.1 \\
32.3 \\
32.9 \\
32.8 \\
31.9\end{array}$ & $\begin{array}{l}13898.3 \\
13890.8 \\
13891.8 \\
13894.7 \\
13899.5 \\
13892.8\end{array}$ & $\begin{array}{l}13892.6 \\
13885.2 \\
13886.1 \\
13889.0 \\
13893.8 \\
13887.2\end{array}$ \\
\hline \multicolumn{5}{|c|}{$\begin{array}{l}\text { Mean } \\
\text { Standard deviation of the mean }\end{array}$} & $\begin{array}{r}13889.0 \\
\quad \pm 1.4\end{array}$ \\
\hline \multicolumn{6}{|c|}{ Sample GL-658 } \\
\hline $\begin{array}{l}1 \\
2 \\
3 \\
4 \\
5 \\
6\end{array}$ & $\begin{array}{l}0.92538 \\
.89375 \\
.90330 \\
.88723 \\
.85106 \\
.88153\end{array}$ & $\begin{array}{l}\text { 3. } 01453 \\
\text { 2. } 91014 \\
\text { 2. } 94091 \\
\text { 2. } 88905 \\
\text { 2. } 77228 \\
\text { 2. } 87141\end{array}$ & $\begin{array}{l}31.8 \\
32.0 \\
31.2 \\
31.3 \\
30.6 \\
31.0\end{array}$ & $\begin{array}{l}13747.3 \\
13753.4 \\
13747.1 \\
13747.3 \\
1377.2 \\
13746.3\end{array}$ & $\begin{array}{l}13741.6 \\
13747.7 \\
13741.5 \\
13741.7 \\
13741.7 \\
13740.7\end{array}$ \\
\hline \multicolumn{5}{|c|}{$\begin{array}{l}\text { Mean } \\
\text { Standard deviation of the mean }\end{array}$} & $\begin{array}{r}13742.5 \\
\quad \pm 1.2\end{array}$ \\
\hline \multicolumn{6}{|c|}{ Sample X-452 } \\
\hline $\begin{array}{l}1 \\
2 \\
3 \\
4 \\
6 \\
7\end{array}$ & $\begin{array}{l}1.15567 \\
0.95626 \\
.78384 \\
.80454 \\
.89381 \\
.88746 \\
.85707\end{array}$ & $\begin{array}{l}\text { 3. } 78352 \\
\text { 3. } 13200 \\
\text { 2. } 56602 \\
\text { 2. } 63482 \\
\text { 2. } 92658 \\
\text { 2. } 90639 \\
\text { 2. } 80670\end{array}$ & $\begin{array}{l}31.4 \\
30.7 \\
31.5 \\
30.8 \\
31.7 \\
30.7 \\
31.6\end{array}$ & $\begin{array}{l}\text { 13498. } 7 \\
13491.9 \\
13499.7 \\
13498.2 \\
13500.6 \\
13495.3 \\
13501.1\end{array}$ & $\begin{array}{l}13492.5 \\
13486.7 \\
13494.0 \\
13492.6 \\
13494.8 \\
13489.6 \\
13495.3\end{array}$ \\
\hline \multicolumn{5}{|c|}{$\begin{array}{l}\text { Mean } \\
\text { Standard deviation of the mean }\end{array}$} & $\begin{array}{r}13492.1 \\
\pm 1.2\end{array}$ \\
\hline \multicolumn{6}{|c|}{ Sample GL-662 } \\
\hline $\begin{array}{l}1 \\
2 \\
3 \\
4 \\
5 \\
5 \\
-\end{array}$ & $\begin{array}{l}0.94737 \\
.94541 \\
.96905 \\
.85475 \\
.89713 \\
.89258\end{array}$ & $\begin{array}{l}\text { 3. } 12610 \\
\text { 3. } 12019 \\
\text { 3. } 19821 \\
\text { 2. } 82085 \\
\text { 2. } 96068 \\
\text { 2. } 94579\end{array}$ & $\begin{array}{l}31.6 \\
32.0 \\
31.6 \\
31.7 \\
30.7 \\
31.5\end{array}$ & $\begin{array}{l}13183.4 \\
13180.1 \\
13189.0 \\
13183.8 \\
13182.3 \\
13188.2\end{array}$ & $\begin{array}{l}13177.3 \\
13173.9 \\
13182.8 \\
13177.9 \\
13176.3 \\
13182.2\end{array}$ \\
\hline \multicolumn{5}{|c|}{$\begin{array}{l}\text { Mean } \\
\text { Standard deviation of the mean }\end{array}$} & $\begin{array}{r}13178.4 \\
\pm 1.4\end{array}$ \\
\hline \multicolumn{6}{|c|}{ Sample $48-\mathrm{B}$} \\
\hline $\begin{array}{l}1 \\
2 \\
3 \\
4 \\
5 \\
6\end{array}$ & $\begin{array}{l}0.92042 \\
.91594 \\
.94733 \\
.93335 \\
.96567 \\
.94315\end{array}$ & $\begin{array}{l}\text { 3. } 05117 \\
\text { 3. } 03606 \\
\text { 3. } 13950 \\
\text { 3. } 09382 \\
\text { 3. } 20112 \\
\text { 3. } 12581\end{array}$ & $\begin{array}{l}33.9 \\
30.6 \\
30.9 \\
31.4 \\
30.9 \\
30.8\end{array}$ & $\begin{array}{l}12963.7 \\
12963.9 \\
12965.5 \\
12965.4 \\
12970.3 \\
12971.1\end{array}$ & $\begin{array}{l}12957.1 \\
12957.8 \\
12959.4 \\
12959.2 \\
12964.2 \\
12965.0\end{array}$ \\
\hline $\begin{array}{l}\text { Mean } \\
\text { Standard }\end{array}$ & iation & 7 & 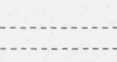 & & $\begin{array}{r}12960.4 \\
\quad \pm 1.4\end{array}$ \\
\hline
\end{tabular}

a The data on this sample are for $30^{\circ} \mathrm{C}$.
TABLE 4. Results of bomb-calorimetric measurements $5^{\circ} \mathrm{C}$ polymers

\begin{tabular}{|c|c|c|c|c|c|}
\hline \multirow{2}{*}{ Experiment } & \multirow{2}{*}{$\begin{array}{l}\text { Mass of } \\
\text { sample }\end{array}$} & \multirow{2}{*}{$\underset{\mathrm{CO}_{2}}{\text { Mass of }}$} & \multirow{2}{*}{$\begin{array}{l}\text { Initial } \cap_{2} \\
\text { pressure } \\
\text { at } 28^{\circ} \mathrm{C}\end{array}$} & \multicolumn{2}{|c|}{$\begin{array}{c}\text { Energy of combustion } \\
\text { at } 28^{\circ} \mathrm{C} \text {. }\end{array}$} \\
\hline & & & & $-\Delta U_{B}$ & $-\Delta U_{c}^{\circ}$ \\
\hline \multicolumn{6}{|c|}{ Sample B } \\
\hline $\begin{array}{l}1 \\
2 \\
2 \\
3 \\
4\end{array}$ & $\begin{array}{r}g \\
0.90075 \\
.94306 \\
.93426 \\
.91407\end{array}$ & $\begin{array}{l}\stackrel{g}{ } \\
\text { 2. } 91395 \\
\text { 3. } 04831 \\
\text { 3. } 02307 \\
\text { 2. } 95543\end{array}$ & $\begin{array}{l}\text { atm } \\
30.9 \\
31.6 \\
31.8 \\
31.2\end{array}$ & $\begin{array}{l}j / g \mathrm{CO}_{2} \\
13876.6 \\
13875.0 \\
13875.3 \\
13885.8\end{array}$ & $\begin{array}{l}\mathrm{J} / \mathrm{g} \mathrm{CO}_{2} \\
13871.1 \\
13869.3 \\
13869.6 \\
13880.2\end{array}$ \\
\hline \multicolumn{5}{|c|}{$\begin{array}{l}\text { Mean } \\
\text { Standard deviation of the mean }\end{array}$} & $\begin{array}{r}13872.6 \\
\quad \pm 2.6\end{array}$ \\
\hline \multicolumn{6}{|c|}{ Sample X-454 } \\
\hline $\begin{array}{l}1 \\
2 \\
3 \\
4\end{array}$ & $\begin{array}{r}0.90962 \\
.91191 \\
.89449 \\
.90816\end{array}$ & $\begin{array}{l}\text { 2. } 95790 \\
\text { 2. } 96572 \\
\text { 2. } 90938 \\
\text { 2. } 95355\end{array}$ & $\begin{array}{l}31.6 \\
32.6 \\
33.4 \\
32.1\end{array}$ & $\begin{array}{l}13670.5 \\
13672.7 \\
13675.1 \\
13665.1\end{array}$ & $\begin{array}{l}13664.8 \\
13666.9 \\
13669.2 \\
13659.3\end{array}$ \\
\hline \multicolumn{5}{|c|}{$\begin{array}{l}\text { Mean } \\
\text { Standard deviation of the mean }\end{array}$} & $\begin{array}{r}13665.1 \\
\quad \pm 2.1\end{array}$ \\
\hline \multicolumn{6}{|c|}{ Sample $\mathrm{X}-478$} \\
\hline $\begin{array}{l}1 \\
2 \\
2 \\
3 \\
4\end{array}$ & $\begin{array}{r}0.91363 \\
.94549 \\
.89638 \\
.92084\end{array}$ & $\begin{array}{l}\text { 2. } 99146 \\
\text { 3. } 09588 \\
\text { 2. } 93456 \\
\text { 3. } 01664\end{array}$ & $\begin{array}{l}32.0 \\
31.6 \\
31.9 \\
31.2\end{array}$ & $\begin{array}{l}13508.7 \\
13502.7 \\
13493.7 \\
13501.7\end{array}$ & $\begin{array}{l}13504.6 \\
13498.7 \\
13494.6 \\
13495.9\end{array}$ \\
\hline \multicolumn{5}{|c|}{$\begin{array}{l}\text { Mean } \\
\text { Standard deviation of the mean }\end{array}$} & $\begin{array}{r}13498.4 \\
\quad \pm 2.2\end{array}$ \\
\hline \multicolumn{6}{|c|}{ Sample GL-660 } \\
\hline $\begin{array}{l}1 \\
2 \\
3 \\
4 \\
5\end{array}$ & $\begin{array}{r}0.91793 \\
.93561 \\
.88791 \\
.87460 \\
.93032\end{array}$ & $\begin{array}{l}\text { 3. } 02034 \\
\text { 3. } 07898 \\
\text { 2. } 92170 \\
\text { 2. } 87793 \\
\text { 3. } 06082\end{array}$ & $\begin{array}{l}31.9 \\
32.1 \\
32.0 \\
32.0 \\
31.9\end{array}$ & $\begin{array}{l}13287.8 \\
13289.6 \\
13283.4 \\
13284.0 \\
13292.2\end{array}$ & $\begin{array}{l}13231.8 \\
13283.5 \\
13277.4 \\
13278.0 \\
13286.1\end{array}$ \\
\hline \multicolumn{5}{|c|}{$\begin{array}{l}\text { Mean } \\
\text { Standard deviation of the mean }\end{array}$} & $\begin{array}{r}13281.4 \\
\quad \pm 1.7\end{array}$ \\
\hline \multicolumn{6}{|c|}{ Sample GL-661 } \\
\hline $\begin{array}{l}1 \\
2 \\
3 \\
4\end{array}$ & $\begin{array}{r}0.93293 \\
.92041 \\
.90656 \\
.91953\end{array}$ & $\begin{array}{l}\text { 3. } 03957 \\
\text { 3. } 04775 \\
\text { 3. } 00149 \\
\text { 3. } 04417\end{array}$ & $\begin{array}{l}32.7 \\
32.6 \\
32.6 \\
32.9\end{array}$ & $\begin{array}{l}13015.4 \\
13011.2 \\
13015.4 \\
13023.4\end{array}$ & $\begin{array}{l}\text { 13009. } 1 \\
\text { 13004. } 9 \\
13009.1 \\
13017.0\end{array}$ \\
\hline \multicolumn{5}{|c|}{$\begin{array}{l}\text { Mean } \\
\text { Standard deviation of the mean }\end{array}$} & $\begin{array}{r}13010.0 \\
\quad \pm ? .6\end{array}$ \\
\hline
\end{tabular}

The values obtained experimentally for the mass of carbon dioxide formed during the combustion are less than those calculated from the carbon content of the samples based on the elemental analysis, the maximum difference being about 0.2 percent. The apparatus for determining the carbon dioxide was tested several times during the course of the work, using NBS Standard Sample $39 \mathrm{~g}$ of benzoic acid, and was found to give results that check the stoichiometric values within 0.01 percent on the average. The difference between the observed and stiochiometric values for the mass of carbon dioxide formed during the combustion of a polymer is probably due to moisture absorbed by the sample.

The results reported in tables 3 and 4 include the heat of combustion of the phenyl-beta-naphthylamine that was added to the samples as an antioxident. These results were corrected for the heat 
of combustion, $\left(-\Delta U_{c}^{\circ}, 25^{\circ} \quad \mathrm{C}=8305.7 \mathrm{kj} / \mathrm{mole}\right.$, [9]) of this material on the assumption that there was no reaction between the antioxident and the polymer or air. Table 5 presents these corrected values of $-\Delta U_{c}^{\circ}$ and also the corresponding values for $-\Delta H_{c}^{\circ}$ $\left(25^{\circ} \mathrm{C}\right)$ and $\Delta H_{f}^{\circ}\left(25^{\circ} \mathrm{C}\right)$ used in the calculations of heat of polymerization.

TABLE 5. Corrected values of heat of combustion, and the corresponding values of heat of formation per gram of carbon dioxide formed in combustion

\begin{tabular}{|c|c|c|c|c|c|c|}
\hline Sample & $\begin{array}{l}\text { Buta- } \\
\text { diene }\end{array}$ & Styrene & $\begin{array}{c}\text { Mer- } \\
\text { captan }\end{array}$ & $\begin{array}{l}-\Delta U^{\circ} \stackrel{\circ}{c} \\
\left(28^{\circ} \mathrm{C}\right)\end{array}$ & $\begin{array}{l}-\Delta H_{c}^{\circ} \\
\left(25^{\circ} \mathrm{C}\right)\end{array}$ & $\begin{array}{c}\Delta H_{f}^{\circ} \\
\left(25^{\circ} \mathrm{C}\right)\end{array}$ \\
\hline \multicolumn{7}{|c|}{$50^{\circ} \mathrm{C}$ polymers } \\
\hline $\begin{array}{l}\text { A } \\
\text { GI }-657 \\
\text { GL-658 } \\
\text { X-452 } \\
\text { GL-662 } \\
48-B\end{array}$ & $\begin{array}{c}\text { Mole\% } \\
99.815 \\
99.878 \\
95.123 \\
85.840 \\
71.742 \\
60.402\end{array}$ & $\begin{array}{l}\text { Mole \% } \\
0 \\
0 \\
4.656 \\
13.994 \\
28.085 \\
39.492\end{array}$ & $\begin{array}{c}\text { Mole\% } \\
0.184 \\
.122 \\
.241 \\
.166 \\
.173 \\
.107\end{array}$ & $\begin{array}{c}j / g \mathrm{CO}_{2} \\
13877.9 \pm 3.3^{\mathrm{a}} \\
13891.5 \pm 3.6 \\
13744.4 \pm 3.2 \\
13493.2 \pm 3.1 \\
13179.7 \pm 3.6 \\
12961.2 \pm 3.1\end{array}$ & $\begin{array}{c}j / g \mathrm{CO}_{2} \\
13901.0 \\
13914.6 \\
13766.9 \\
13514.6 \\
13200.0 \\
12980.3\end{array}$ & $\begin{array}{c}j / g \mathrm{CO}_{2} \\
73.3 \\
92.0 \\
78.8 \\
87.5 \\
86.5 \\
79.3\end{array}$ \\
\hline \multicolumn{7}{|c|}{$5^{\circ} \mathrm{C}$ polymers } \\
\hline $\begin{array}{l}\text { B } \\
X-454 \\
X-478 \\
\text { GL-660 } \\
\text { GL-661 }\end{array}$ & $\begin{array}{l}99.859 \\
95.258 \\
86.746 \\
77.114 \\
62.916\end{array}$ & $\begin{array}{l}0 \\
\text { 4. } 644 \\
\text { 13. } 162 \\
22.784 \\
36.982\end{array}$ & $\begin{array}{r}0.141 \\
.099 \\
.091 \\
.103 \\
.102\end{array}$ & $\begin{array}{l}13875.4 \pm 4.0 \\
13667.5 \pm 3.8 \\
13498.4 \pm 3.7 \\
13283.0 \pm 3.5 \\
13011.3 \pm 4.0\end{array}$ & $\begin{array}{l}13898.6 \\
13690.0 \\
13519.8 \\
13302.5 \\
13030.4\end{array}$ & $\begin{array}{l}74.5 \\
13.5 \\
77.8 \\
84.6 \\
87.1\end{array}$ \\
\hline
\end{tabular}

a The number following each \pm sign was obtained by appropriately combining the standard deviations of the mean results of calibration and combustion experiments with an estimate $(0.005 \%)$ of the standard deviation of the value used for the heat of combustion of benzoic acid, and an allowance $(0.02 \%)$ for systematic errors due to other factors, especially impurities in the samples.

\section{Calculation of Heat of Polymerization}

In the case of a polymer such as polystyrene, which consists entirely of styrene units joined together, the heat of polymerization is easily calculated as the difference between heats of combustion per monomer unit of monomer and polymer. A similar calculation could also be made of the heat of copolymerization of two monomers, provided the copolymer contained practically nothing except the two kinds of monomer units. The polymers and copolymers investigated in the present work, however, were prepared by using dodecyl mercaptan as a modifier, so that the calculation of heat of polymerization could not be made by the simple method indicated above.

The calculations made here are based on the chain-transfer theory of polymerization, from which it can be assumed that each polymer molecule contains one dodecyl mercaptan molecule chemically combined with it $[10,11]$. In other words, it is assumed that the formula for a polymer molecule can be written $\mathrm{C}_{12} \mathrm{H}_{25} \mathrm{~S} \quad\left(\mathrm{C}_{4} \mathrm{H}_{6}\right)_{m}\left(\mathrm{C}_{8} \mathrm{H}_{8}\right)_{n} \mathrm{H}$, where $m$ and $n$ represent the number of butadiene and styrene units, respectively, in the molecule. ${ }^{2}$ The values of $m$ and $n$ can be calculated from the elemental analysis

${ }^{2}$ Although this assumption is plausible, and is supported by experimental data [10], it is made here merely as a matter of convenience, in order to simplify the calculation of heats of polymerization. Substantially the same result would be obtained if it were assumed that some of the polymer molecules had mercaptain units at both ends and that the others had hydrogen atoms at both ends.

The calculations were actually made on the assumption that a butadiene unit The calculations were actually made on the assumption that a butadiene unit
was attached to the mer captan unit in each molecule. The results would not bo changed appreciably by assuming that a styrene unit was attached to the mercaptan. of the sample. Then the heat of formation of this molecule can be obtained by combining the experimental value for its heat of combustion, according to eq 1 with values for the heats of formation of gaseous carbon dioxide, gaseous sulfur dioxide, and liquid water. The heat, $\Delta H^{\circ}$, of the reaction

$$
\begin{gathered}
\mathrm{C}_{12} \mathrm{H}_{25} \mathrm{SCH}_{2} \mathrm{CH}=\mathrm{CHCH}_{3} \text { (liq) }+(m-1) \mathrm{CH}_{2}= \\
\mathrm{CHCH}=\mathrm{CH}_{2} \text { (liq) }+n \mathrm{CH}_{2}=\mathrm{CHC}_{6} \mathrm{H}_{5} \text { (liq) } \rightarrow \\
\mathrm{C}_{12} \mathrm{H}_{25} \mathrm{~S}\left(\mathrm{C}_{4} \mathrm{H}_{6}\right)_{m}\left(\mathrm{C}_{8} \mathrm{H}_{8}\right)_{n} \mathrm{H} \text { (solid polymer) }
\end{gathered}
$$

can then be calculated from the heats of formation of the solid polymer and of the reactants. The heat of copolymerization is taken as $\left(\Delta H_{p}^{\circ}=\Delta H^{\circ} /[(m+n)]\right.$.

Accurate values for the heats of formation of 1,3butadiene [13, 17] and styrene [18] are available, and are given in table 6 . No data on the heat of formation of $\mathrm{C}_{12} \mathrm{H}_{25} \mathrm{SCH}_{2} \mathrm{CH}=\mathrm{CHCH}_{3}$ have been found in the literature. Fortunately, only an approximate value is required for the present purpose, and such an approximate value was calculated from other data given in table 6, together with the indicated estimated values for the heats of the following reactions at $25^{\circ} \mathrm{C}$ :

$n \mathrm{C}_{16} \mathrm{H}_{34}($ liq $)+\mathrm{S}($ rhombic $) \rightarrow$

$$
n \mathrm{C}_{16} \mathrm{H}_{33} \mathrm{SH}(\mathrm{liq}) ; \Delta H^{\circ}=5.6 \mathrm{kcal}
$$

$n \mathrm{C}_{16} \mathrm{H}_{33} \mathrm{SH}(\mathrm{liq}) \rightarrow$

$$
n \mathrm{C}_{12} \mathrm{H}_{25} \mathrm{SC}_{4} \mathrm{H}_{9} \text { (liq) } ; \Delta H^{\circ}=2.4 \mathrm{kcal}
$$

$n \mathrm{C}_{12} \mathrm{H}_{25} \mathrm{SC}_{4} \mathrm{H}_{9}(\mathrm{liq}) \rightarrow$

$$
\begin{array}{r}
n \mathrm{C}_{12} \mathrm{H}_{25} \mathrm{SCH}_{2} \mathrm{CH}=\mathrm{CHCH}_{3}(\mathrm{liq})+ \\
\mathrm{H}_{2}(\mathrm{~g}) ; \Delta H^{\circ}=28.1 \mathrm{kcal} .
\end{array}
$$

The value of $\Delta H^{\circ}$ for reaction (3) was taken as equal to the difference between the heats of formation of $n$-pentane and $n$-pentanethiol; the value for reaction (4) was taken as the difference between the heats of formation of liquid ethanethiol and liquid dimethylsulphide; the value for reaction (5) was taken as the difference between the heat of formation of liquid $n$-butane and the mean of the heats of formation of cis- and trans-2-butene. The values for the heats of formation of the two butenes were obtained from the corresponding values for the ideal gases [13], together with values of heats of vaporization at $25^{\circ} \mathrm{C}$ to the real gases at saturation pressure [22], that is, the difference in heat content between the real and ideal gases was neglected. The value for the heat of formation of liquid $\mathrm{C}_{12} \mathrm{H}_{25} \mathrm{SCH}_{2} \mathrm{CH}=\mathrm{CHCH}_{3}$ obtained in the manner indicated is $-72.5 \mathrm{kcal} / \mathrm{mole}$. As suggested previously, and as is evident from the method of calculation, this value can only be regarded as approximate.

Values of heats of polymerization and copolymerization calculated as described above are given in table 7 , and are shown plotted against styrene content in figure 1 , where the value $-\Delta H_{p}^{\circ}=16.68$ keal per monomer unit for styrene [12] is also shown. 
TABLE 6. Talues of heats of formation at $25^{\circ} \mathrm{C}$ used in calculating heats of polymerization

\begin{tabular}{|c|c|c|}
\hline Compound & $\Delta H_{f}^{\circ}$ & Reference \\
\hline $\begin{array}{l}n \text {-Pentane (liq) } \\
n \text {-Pentanethiol (liq) } \\
\text { Ethanethiol (liq) } \\
\text { Dimethylsulfide (liq) } \\
n \text {-Butane (liq) } \\
\text { 2-Butene (liq } \\
\text { 1,3-Butadiene (liq. } \\
\text { Styrene (liq) } \\
n \text {-Hexadecane (liq) }\end{array}$ & $\begin{array}{l}k c o l / u \text { ole } \\
-41.36 \\
-35.8 \\
-16 \\
-13.6 \\
-35.51 \\
a-7.43 \\
+20.88 \\
+24.83 \\
-108.59\end{array}$ & $\begin{array}{r}{[14]} \\
15] \\
{[16]} \\
{[16]} \\
{[13,14]} \\
{[13,22]} \\
{[13,17]} \\
{[18]} \\
{[14]}\end{array}$ \\
\hline
\end{tabular}

a Mean of values for cis and trans isomers.

TABLE 7. Heats of polymerization

\begin{tabular}{|c|c|c|}
\hline Sample & $\begin{array}{c}\text { Styrene con- } \\
\text { tent }\end{array}$ & $\begin{array}{l}-\Delta H_{p}^{\circ} \\
\left(25^{\circ} \mathrm{C}\right)\end{array}$ \\
\hline \multicolumn{3}{|c|}{$50^{\circ} \mathrm{C}$ polymers } \\
\hline $\begin{array}{l}\text { A } \\
\text { GL }-657 \\
\text { GL }-658 \\
\text { X-452 } \\
\text { GL }-662 \\
48-B \\
\text { Polystyrene }\end{array}$ & $\begin{array}{c}\text { Mole \% } \%^{a} \\
0 \\
0 \\
4.65 \\
14.02 \\
28.13 \\
39.53 \\
100\end{array}$ & $\begin{array}{c}\text { kcal/mono- } \\
\text { unit } \\
17.6 \\
16.9 \\
17.4 \\
17.1 \\
17.2 \\
17.7 \\
\text { в } 16.7\end{array}$ \\
\hline \multicolumn{3}{|c|}{$5^{\circ} \mathrm{C}$ polymers } \\
\hline $\begin{array}{l}\text { B } \\
\text { X-454 } \\
\text { X-478 } \\
\text { GL }-660 \\
\text { GL }-661\end{array}$ & $\begin{array}{r}0 \\
4.65 \\
13.17 \\
22.84 \\
37.02\end{array}$ & $\begin{array}{l}17.6 \\
20.4 \\
17.6 \\
17.3 \\
17.2\end{array}$ \\
\hline
\end{tabular}

a Mole percent styrene plus mole percent butadiene $=100$.

b Roberts, Walton, and Jessup [12]. This sample contained no sulfur, and the heat of polymerization was calculated as the difference between the heatof combustion per monomer-unit of polymer and monomer.

\section{Discussion}

It is apparent from figure 1 that the value 20.4 kcal per monomer unit for $-\Delta H^{\circ}$ for the $5^{\circ} \mathrm{C}$ polymer $\mathrm{X}-454$ is entirely out of line with the values for the other polymers, which range from 16.9 to 17.7 kcal per monomer unit. No satisfactory explanation of this high value has been found, but the reasonably good consistency of the data on the other polymers suggests that the high value of $-\Delta H^{\circ}$ for sample $\mathrm{X}-454$ may be related to some abnormality in the composition of this sample. Some abnormality in this sample is also indicated by a correlation of the refractive indices of the various polymers with styrene content [20]. It has been found that the styrene contents of the other $5^{\circ} \mathrm{C}$ polymers, as determined from analyses for carbon, hydrogen, and sulfur, can be represented by an empirical function of refractive index within a few thousandths of 1 percent of styrene. However, this relation gives a value for styrene content for sample $\mathrm{X}-454$ that is lower than the value calculated from the analysis of the sample by approximately 0.5 percent.

As stated previously, a part of the sulfur in sample $\mathrm{X}-454$ was present as inorganic impurity, and it may be that the inorganic sulfur compound took

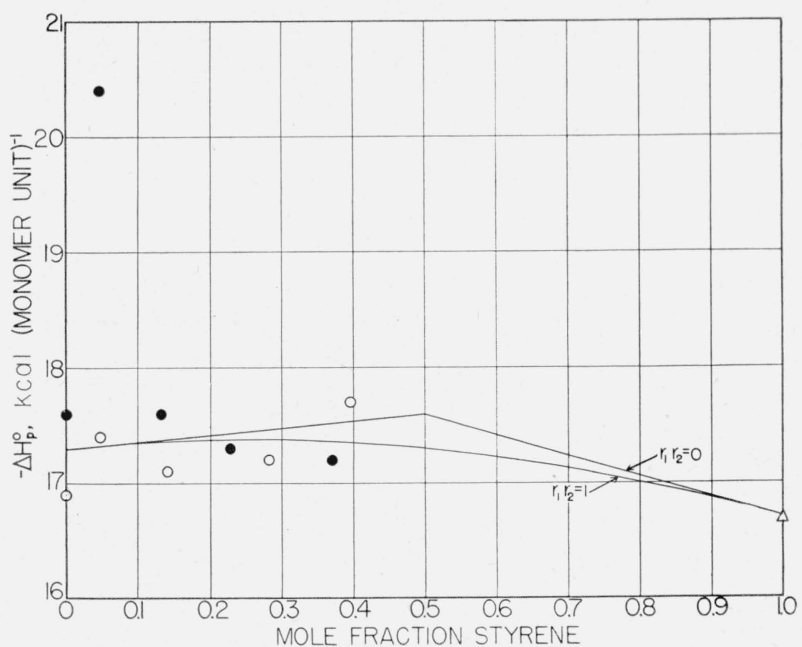

Figure 1. Heats of copolymerization.

$\bigcirc, 50^{\circ} \mathrm{C}$ polymers; $-5^{\circ} \mathrm{C}$ polymers; $\triangle$, polystyrene

part in some reaction in the bomb. Since the nature of the sulfur compound is not known, no correction for the effect of such reactions could be made. Calculated values of the correction on the basis of various assumptions as to what sulfur compounds may have been present and what reactions may have taken place indicate that the error introduced by neglecting the thermal effect of the reaction, and by making corrections for nitric and sulfuric acids as described previously, probably does not exceed 0.02 or 0.03 percent of the heat of combustion. This is far too small to account for the abnormal result obtained with sample $\mathrm{X}-454$.

It will be seen from figure 1 that the values of $-\Delta H_{p}^{\circ}$ for samples other than $\mathrm{X}-454$ do not indicate any appreciable difference between the $5^{\circ} \mathrm{C}$ and the $50^{\circ} \mathrm{C}$ polymers. It will be seen also that the points for polymers other than $\mathrm{X}-454$ lie reasonably near to the curves shown. The maximum deviation from either curve corresponds to about 0.06 percent in heat of combustion of the polymer. This is probably as good agreement as could be expected. considering the nature of the polymeric materials and the approximations made in calculating the heats of polymerization.

The curves shown in figure 1 were calculated from an equation of a form derived theoretically by Alfrey and Lewis [19], which expresses heat of copolymerization as a function of copolymer composition. A value for one of the two parameters in this equation was chosen empirically to fit the experimental data. According to Alfrey and Lewis [19] the other parameter, designated as $r_{1} r_{2}$, was less than or equal to unity in all copolymer pairs studied by them. The two curves shown in figure 1 may therefore represent the limits between which the best theoretical curve would lie. It is seen from figure 1 that the data are at least not inconsistent with the theoretical curves. It may be noted also that the deviation of the curves from a straight line connecting the values for 0 and 100 percent of 
styrene is in the direction predicted by Alfrey and Lewis. It should be pointed out, however, that the polymers investigated here were prepared under conditions such that conversion ranged from 60 to 75 percent, whereas Alfrey and Lewis [19] state that their analysis applies only for low-conversion polymerization, without appreciable drift in monomer ratio.

It seems unlikely from the information available on the polymers investigated and from the results of infrared studies on similar polymers by Hart and Meyer [8] that any appreciable differences in heat of polymerization would arise from differences in the relative amounts of 1,2 and cis- and trans-1,4 structures in various polymer samples.

The authors are indebted to Max Tryon of the Rubber Section of the Bureau for purifying the various polymer samples; to Rolf $A$. Paulson of the Analytical Chemistry Section for the chemical analyses reported in table 1 ; to W. N. Hubbard and Guy Waddington, U. S. Bureau of Mines Experiment Station, Bartlesville, Okla., for permission to use their preliminary value for the heat of formation of $n$-pentanethiol.

\section{References}

[1] H. C. Dickinson, Bul. BS 11, 189 (1914) S230.

[2] R. S. Jessup and C. B. Green, J. Research NBS 13, 469 (1934) RP721.

[3] R. S. Jessup, J. Reaearch NBS 29, 247 (1942) RP1499.

[4] R. S. Jessup, J. Research NBS 36, 421 (1946) RP1711.

[5] F. B. Silsbee, NBS Circular 475 (1949).
[6] M. Shepherd, Anal. Chem. 19, 77 (1947).

[7] E. W. Washburn, BS J. Research 10, 525, (1933) RP546.

[8] E. J. Hart and A. W. Meyer, J. Am. Chem. Soc. 71, $1980(1949)$

[9] D. E. Roberts and R. S. Jessup, J. Research NBS 40, 281 (1948) RP1873.

[10] H. R. Snyder, J. M. Stewart, R. E. Allen, and R. J. Dearborn, J. Am. Chem Soc. 68, 1422 (1946).

[11] F. T. Wall, F. W. Banes, and G. D. Sands, J. Am. Chem. Soc. 68, 1429 (1946).

[12] D. E. Roberts, W. W. Walton, and R. S. Jessup, J. Research NBS 38, 627 (1947) RP1801.

[13] E. J. Prosen, F. W. Maron, and F. D. Rossini, J. Research, NBS 46, 106 (1951) RP2181.

[14] E. J. Prosen and F. D. Rossini, J. Research NBS 34, 263 (1945) RP1642.

[15] W. N. Hubbard and Guy Waddington, U. S. Bureau of Mines Experiment Station, Bartlesville, Okla., Unpublished data.

[16] Selected values of chemical thermodynamic properties, NBS Circular 500 (1952).

[17] E. J. Prosen and F. D. Rossini, J. Research NBS 34, 59 (1945) RP1628.

[18] American Petroleum Institute Research Project 44 at the National Bureau of Standards. Selected values of properties of hydrocarbons. Table 13p, Styrenes (Feb. $28,1949)$.

[19] T. Alfrey, Jr. and Charles Lewis, J. Polymer Sci. IV, 221 (1949).

[20] Max Tryon, Rubber Section, National Bureau of Standards, unpublished data. See also Specifications for Government Synthetic Rubber, Revised ed., issued by Reconstruction Finance Corp., Office of Rubber Reserve, 811 Vermont Ave., Washington 25, D. C., Section C 6, 1-1-51.

[21] E. Wichers, J. Am. Chem. Soc. \%, 1431 (1950).

[22] Selected values of properties of hydrocarbons, NBS Circular 461, Table 8m, p. 139 (1947)

WA shington, July 26, 1951 . 